\title{
Forest Commons Use in India: A Case Study of Van Panchayat in the Himalayas Reveals People's Perception and Characteristics of Management Committee
}

\author{
Kazuyo Nagahama ${ }^{1, *}$, Kaoru Saito ${ }^{1}$, Misa Masuda ${ }^{2}$, Masahiko Ota ${ }^{3}$, Hem Gairola ${ }^{4}$, \\ Subodh Kumar Kala ${ }^{5}$, Randeep Rakwal ${ }^{6}$ \\ ${ }^{1}$ Graduate School of Frontier Sciences, The University of Tokyo, Japan \\ ${ }^{2}$ Faculty of Life and Environmental Sciences, University of Tsukuba, Japan \\ ${ }^{3}$ Learning \& Teaching Center, Kyushu Institute of Technology, Kitakyushu, Japan \\ ${ }^{4}$ Garhwal Environment and Education Society, India \\ ${ }^{5}$ Forest Department of Uttarakhand, India \\ ${ }^{6}$ Faculty of Health and Sport Sciences and Tsukuba International Academy for Sport Studies, University of Tsukuba, Japan
}

Copyright $(2016$ by authors, all rights reserved. Authors agree that this article remains permanently open access under the terms of the Creative Commons Attribution License 4.0 International License

\begin{abstract}
Van (forest) Panchayat (hereafter $V P$ ) is one of the largest and most diverse experiments in common property resource management in the Himalayan ranges of the state of Uttarakhand, India. The idea of establishing $V P$ originated in conflicts between people and the British authorities for controlling resources. The people of this region are dependent on the utilization of forest products, such as firewood and non-timber forest products for their livelihood. In this study, a field survey was carried out on $V P$ in the village, named " $D$ " village of Tehri-Garhwal district in the state of Uttarakhand, in order to investigate VPs impact on people's livelihood with a focus on the participation of the people in forest management. Two study objectives were examined as follows: first, to clarify the people's perception under the $V P$, and second, to reveal the characteristics of the $V P$ management committee (MC), which is directly responsible for managing the community forests. We used the semi-structured interview approach to determine the villagers' perception for the $V P$ activities and condition of the community forest. Results revealed people's satisfaction with the condition of the $V P$ and common utilization of the forest resources. In case of the MC, people did not appear to show an overall interest such as not joining the meetings and activities. The reason for this can be related to the organization of the $\mathrm{MC}$ that was functioning for more than 20 years with the same leadership and almost unchanged MC members. To summarize, people's participation in the forest utilization was not only dependent on their own personal contribution towards $V P$ activities, but also more importantly, on their involvement in the forest management via the MC.
\end{abstract}

Keywords Van Panchayat, Community-based Forest
Management,
Participation

\section{Introduction}

In the 1960s and 1970s, pressure on forests in developing countries intensified due to poverty and population growth, in particular India, leading the forest management authorities to recognize the socio-economic aspects of local population such as social forestry. During the early phases of social forestry policy, spanning the 1970 s to the 1980 s, the primary focus was on how to reduce people's use of forest resources. For example, programs were developed to provide local people with seedlings for creating woodlots on private land, to establish alternative energy facilities to reduce firewood use, to help in the construction of village infrastructure and / or to promote employment outside of the forests. These social forestry practices resembled integrated conservation and development projects in protected areas after the 1980s $[1,2]$. Seemingly good on the surface, there was a drawback in these practices in that the local people were kept away from the decision-making processes regarding the public forests [3].

Until the late 1980s, national forest policies in India emphasized the optimization of commercial forestry, which prohibited local villagers' access to forests [4]. The result was a rapid and widespread degradation of forests, exposing the failure of top-down state forest resource management policies. Frequent conflicts also arose between the forest department (hereafter, FD) and local forest users, i.e. the villagers. It was then that the local government became aware of the important roles forests have and play in supporting the livelihoods of the local people [5]. In the 1990 s, the forestry sector was gradually decentralized to 
create greater efficiency, accountability, and cost cutting [6]. Hence, the government began to acknowledge a certain right and authority of local communities to the management of state forests. This idea of community-based forest management (hereafter, CBFM) has been observed in the developing countries, including India, since the 1990s. India was one of the first countries to introduce CBFM as the Joint Forest Management (hereafter, JFM) policy implemented since the early 1990s [5].

The state of Uttarakhand in North West India has been practicing decentralized forest management for almost 60 years before the initiation of JFM. This is the self-initiated forest protection group called Van panchayat (hereafter VP; "Van" means forest in Hindi, "VP" means "Panchayati Forest"), and which is governed by the $V P$ rules, first published in 1931, revised in 1976, 2001 and in 2005. Accordingly, all the villagers are members of the $V P$ upon its approval by the Sub-Divisional Magistrate under the Revenue Department (RD) of the state. They are collectively referred to as the general body (hereafter, GB) that selects the Management Committee (hereafter, MC) members through a democratic process. The $V P$ s are best examples of age-old institutions $[7,8] .^{\text {see Note } 1}$ Both institutions have emerged out of persistent conflicts between people and the government regarding their control over forest resources [9, $10]$.

The number of $V P s$ has increased gradually and then more rapidly since 1990 (Figure 1). However, there is a steady decline in $V P$ practice and a quantitative and qualitative decline of the once dense and well-managed forests in the Kumaon hills in the central Himalayas [11]. There are other aspects regarding $V P \mathrm{~s}$ on the decline: it has been pointed out that due to the increasing control of the RD and FD and poor support system, $V P \mathrm{~s}$ have been besieged by numerous conflicts and have difficulty in maintaining their proprietary rights [7]. Furthermore, heavy control by the FD over these people's institutions and the loss of autonomy at the grassroots level magnified the conflict within MC. From previous studies, it is clear that $V P \mathrm{~s}$ had once increased the access of local communities to forest resources and demonstrated potentials for better forest management. According to Agrawal (2005) in his book "Regulatory Community", VPs demonstrated good examples of decentralized resource management that benefited local communities [12]. Let us look at one example of when the control is taken over from the local community. The case of Pakhi VP (Kumaon hills) illustrates the effect of the top-down planning and implementation of a 'participatory' forestry project. In this case, the state government of Uttarakhand had tightened its control over the VP management [13]. It received a large amount of money from the state government along with more bureaucratic control over management. As a result, local governance over forests became disempowered. Local power in the $V P$ system in general is in decline because of increasing control by the FD, resulting in the overall loss of autonomy and intensified conflicts within and among the MCs of the VPs [7]. Despite these literatures, there is still a lack of studies focusing on different cases of $V P \mathrm{~s}$, and the conditions behind their failure or success. This was one motivation for conceptualizing the study of $V P$ s practice in the state of Uttarakhand.

In the present study, we have looked at a $V P$, which was suggested by the FD to be a successful case in terms of CBFM, to clarify the actual conditions of forest management and utilization as a case study. Two objectives were as follows: to reveal the people's perception under the $V P$, and to unravel the characteristics of the MC, which is directly responsible for managing the community forests having power for decision-making and rule implementation. To do so, the study was examined using a semi-structured interview-based approach during field trips. We also identified specific problems being faced by the participants of the VP. By analyzing these conditions, the questions on $M C$ 's responsibility and the local livelihood of the villagers are discussed.

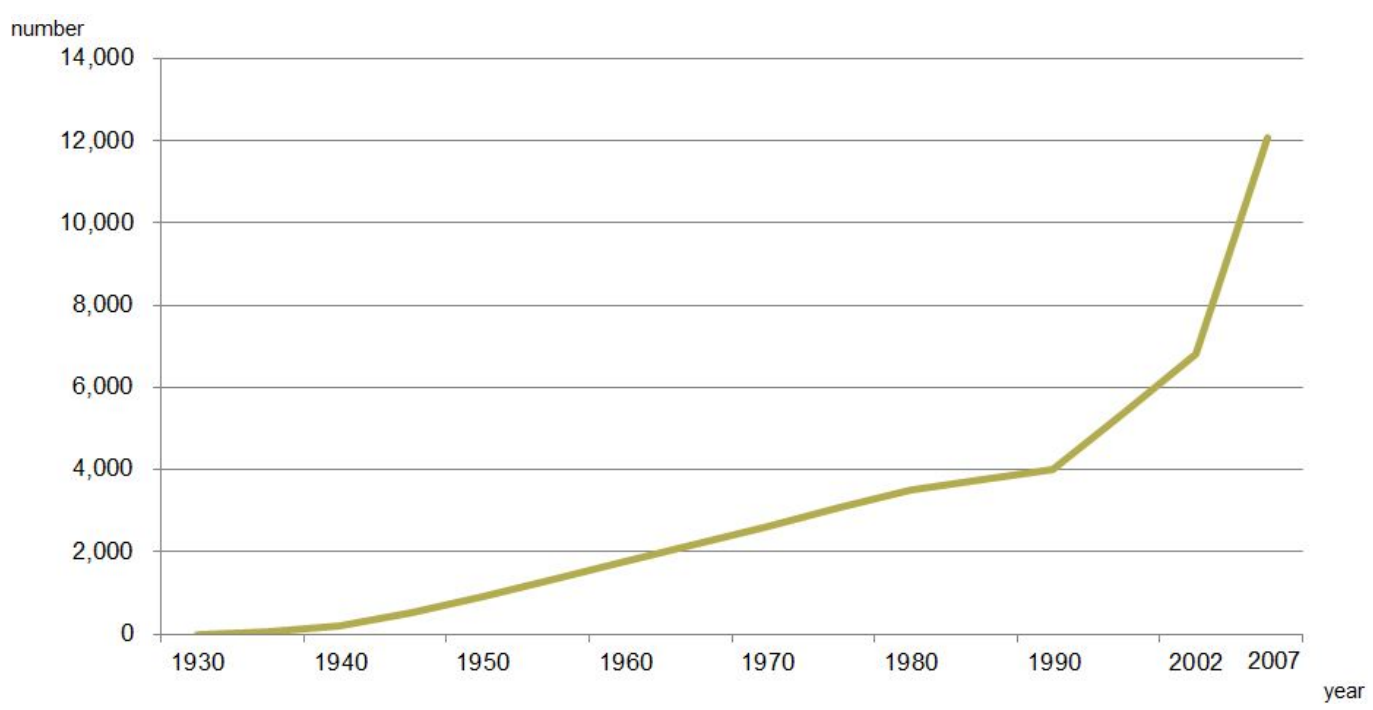

Figure 1. The change of number of $V P \mathrm{~s}[22,23]$ 
Table 1. The number and area size of the $V P$ forests in Uttarakhand

\begin{tabular}{|c|c|c|c|c|c|c|c|c|c|c|c|c|c|c|c|c|c|c|c|c|c|}
\hline \multirow[b]{2}{*}{ Division } & \multirow[b]{2}{*}{ District } & \multirow[b]{2}{*}{$\begin{array}{c}\text { Village } \\
\text { no. }\end{array}$} & \multirow[b]{2}{*}{$\begin{array}{l}\text { VP } \\
\text { no. }\end{array}$} & \multirow{2}{*}{$\begin{array}{l}\text { VP } \\
\text { ratio } \\
(\%)\end{array}$} & \multirow{2}{*}{$\begin{array}{l}\text { VP } \\
\text { area } \\
\text { (ha) }\end{array}$} & \multirow{2}{*}{$\begin{array}{c}\text { VP } \\
\text { area/ } \\
\text { VP no. } \\
\text { (ha) }\end{array}$} & \multicolumn{4}{|c|}{ Year } & \multicolumn{5}{|c|}{ Area (ha) } & \multicolumn{6}{|c|}{ VP area up 1990 (ha) } \\
\hline & & & & & & & $\begin{array}{l}1931- \\
1950\end{array}$ & $\begin{array}{c}1950- \\
1970\end{array}$ & $\begin{array}{c}1970- \\
1990\end{array}$ & $\begin{array}{l}\text { up to } \\
1990\end{array}$ & $0-10$ & $10-50$ & $\begin{array}{l}50- \\
100\end{array}$ & $\begin{array}{l}100- \\
500\end{array}$ & $\begin{array}{c}>50 \\
0\end{array}$ & $<5$ & $\begin{array}{l}5- \\
10\end{array}$ & $\begin{array}{l}10- \\
20\end{array}$ & $\begin{array}{l}20- \\
50\end{array}$ & $\begin{array}{l}50- \\
100\end{array}$ & $\begin{array}{c}>10 \\
0\end{array}$ \\
\hline \multirow{5}{*}{ Garhwal } & Tehri & 1863 & 1332 & 71.50 & 13180 & 9.89 & NA & NA & NA & 535 & 796 & 375 & 24 & 1 & 0 & 222 & 185 & 100 & 25 & 3 & 0 \\
\hline & Uttarakashi & 707 & 644 & 91.09 & 7265 & 11.28 & NA & NA & NA & 293 & 504 & 112 & 20 & 5 & 1 & 157 & 88 & 37 & 8 & 2 & 1 \\
\hline & Pouri & 3485 & 2431 & 69.76 & 52814 & 21.73 & 157 & 414 & 242 & 1607 & 1201 & 1011 & 153 & 62 & 4 & 510 & 494 & 344 & 220 & 31 & 8 \\
\hline & Dehradun & 760 & 215 & 28.29 & 7659 & 35.62 & NA & NA & 74 & NA & 64 & 107 & 21 & 23 & 0 & NA & NA & NA & NA & NA & NA \\
\hline & Chamoli & 1246 & 1082 & 86.84 & 188355 & 174.08 & 48 & 180 & 109 & 491 & 144 & 422 & 136 & 107 & 18 & 32 & 88 & 129 & 129 & 63 & 50 \\
\hline \multirow{5}{*}{ Kumaon } & Almora & 2290 & 2199 & 96.03 & 69853 & 31.77 & 207 & 348 & 447 & 544 & 778 & 1043 & 247 & 127 & 2 & 228 & 106 & 110 & 76 & 21 & 3 \\
\hline & Bagesywal & 947 & 822 & 86.80 & 38783 & 47.18 & 152 & 189 & 186 & 292 & 369 & 323 & 69 & 47 & 14 & 108 & 68 & 64 & 35 & 12 & 5 \\
\hline & Champayat & 718 & 629 & 87.60 & 31233 & 49.65 & 42 & 168 & 58 & 358 & 199 & 283 & 82 & 60 & 2 & 88 & 88 & 96 & 69 & 12 & 5 \\
\hline & Piutragal & 1675 & 1666 & 99.46 & 87054 & 52.25 & 141 & 234 & 152 & 812 & 629 & 564 & 194 & 148 & 12 & 296 & 170 & 154 & 107 & 54 & 31 \\
\hline & Nainital & 1155 & 495 & 42.86 & 28068 & 56.70 & 64 & 109 & 21 & 301 & 155 & 200 & 64 & 71 & 5 & 82 & 64 & 66 & 59 & 18 & 12 \\
\hline \multicolumn{2}{|c|}{ Total } & 15534 & 12089 & 77.82 & 544964 & 45.08 & 867 & 1756 & 1326 & 5473 & 5203 & 4662 & 1079 & 674 & 42 & 1829 & 1408 & 1137 & 756 & 226 & 117 \\
\hline
\end{tabular}

Data compiled from VP Atlas 2007, Uttarakhand Forest Department; in Bold: the small VPs number and the areas

\section{Materials and Methods}

\subsection{Study Design and Strategy}

To achieve the above-mentioned objectives, the following approaches were undertaken. The first step involves clarifying the actual situation of forest utilization with local people's livelihood activities hinging on the impact of VPS on peoples' lives. The second step characterizes the MC who would be appointed in the context of the micro-plan, i.e. forest management plan under the control of the FD. The field survey was performed in a $V P$ in the Tehri-Garhwal district of Uttarakhand state. Table 1 shows the data for all VPs in Uttarakhand state according to the VP Atlas (2007), and which reveals that may VPs were formed after 1990 [14]. The VPs in Tehri-Garhwal are newly formed and these VPS have a smaller area than other regions/district.

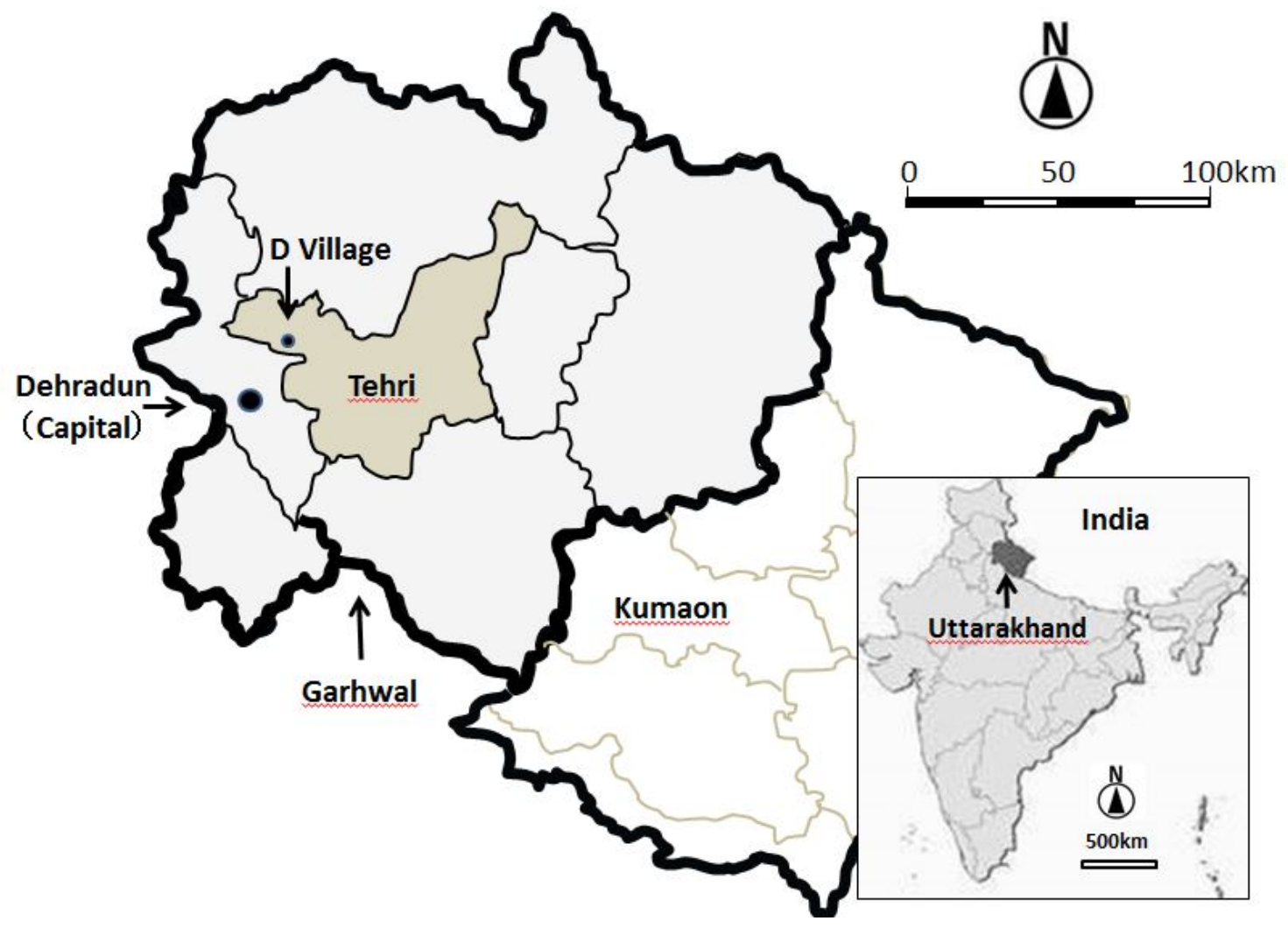

Figure 2. Study field site 
Table 2. Interview with the Sarpanch (Van panchayat leader) at Tehri-Garhwal district

\begin{tabular}{|c|c|c|c|c|c|}
\hline District & \multicolumn{5}{|c|}{ Tehri - Garhwal } \\
\hline VP (Village) & D & $M$ & B & $\mathbf{S}$ & K \\
\hline Household & 51 (OC: 19; SC: 32) & 40 & $\begin{array}{l}85 \text { (OC: Brahmin 60\%, } \\
\text { Rajiput } 40 \% \text {; SC: } 1 \text { ) }\end{array}$ & 42 (OC: 37; SC: 5) & 140 \\
\hline$V P$ established year & 1993 & 2005 & 2003 & 2006 & 2007 \\
\hline Type of forest & $\begin{array}{l}\text { Oak (Quercus spp.) } \\
\text { dominated forest with } \\
\text { some patches of Chir } \\
\text { pine (Pinus roxburghii) }\end{array}$ & $\begin{array}{l}\text { Some broad-leaved } \\
\text { forest trees and Chir } \\
\text { Pine }\end{array}$ & Oak & ND & ND \\
\hline Codition of forest & Fair & Slightly fair (less trees) & Fair & Slightly fair (less trees) & ND \\
\hline $\begin{array}{l}\text { Woman's self supporting } \\
\text { organization group }\end{array}$ & No & $\begin{array}{l}\text { Yes ("Nagrajya Soyam" } \\
\text { and "Saita Samu") }\end{array}$ & No & No & No \\
\hline $\begin{array}{l}\text { Support from NGO / } \\
\text { Government }\end{array}$ & $\begin{array}{l}\text { Bamboo project from } \\
\text { Uttarakhand FD }\end{array}$ & Campa (government) & $\begin{array}{l}\text { Government } \\
\text { agriculture scheme to } \\
\text { Gram Panchayat }\end{array}$ & No project & $\begin{array}{l}\text { Microplan from Agibica } \\
\text { (NGO) }\end{array}$ \\
\hline Area of $V P$ (ha) & 21 ha & 29 ha & 8 ha & 11.8 ha & $18.5 \mathrm{ha}$ \\
\hline Distance to VP (km) & $0.5 \mathrm{~km}$ & & $2 \sim 3 \mathrm{~km}$ & $0.5 \mathrm{~km}$ & $4 \sim 5 \mathrm{~km}$ \\
\hline Area of plantation (ha) & $\begin{array}{c}15 \text { ha (Bamboo, } 10 \text { ha; } \\
\text { Oak, } 5 \text { ha) }\end{array}$ & & & 8 ha & 10 ha \\
\hline Managed before the $V P$ & Civil/Soyam land & Forest Department & ND & ND & JFM: 1999-2003 \\
\hline MC (gender) & $\begin{array}{l}\text { Male: } 5 \\
\text { Female: } 4 \text { (SC: } 1 \text { ) }\end{array}$ & $\begin{array}{l}\text { Male: } 5 \\
\text { Female: } 4\end{array}$ & $\begin{array}{l}\text { Male: } 6 \\
\text { Female: } 3 \text { (SC: 1) }\end{array}$ & $\begin{array}{l}\text { Male: } 6 \\
\text { Female: } 3 \text { (SC: 1) }\end{array}$ & $\begin{array}{l}\text { Male: } 5 \\
\text { Female: } 4\end{array}$ \\
\hline MC (caste) & OC: 6 ; SC: 3 & OC: $7 ;$ SC: 2 & OC: $8 ;$ SC: 1 & OC: $8 ;$ SC: 1 & OC: $7 ;$ SC: 2 \\
\hline Land holding & $\begin{array}{l}\text { Landless: } 0 \\
\text { Small land holder: } 50 \\
\text { (everbody has same } \\
\text { size of agriculture field) }\end{array}$ & Landless: 0 & Landless: 0 & $\begin{array}{l}\text { Landless: } 0 \\
0-3 \text { ha: } 10 \\
\text { 3-5 ha: } 32\end{array}$ & $\begin{array}{l}\text { Landless: } 0 \\
\text { 0-3 ha: } 25 \\
\text { >5 ha: } 10 \sim 20\end{array}$ \\
\hline Microplan & Yes & No & No & Yes & Yes \\
\hline Reason for VP & $\begin{array}{l}\text { Demand from } \\
\text { community }\end{array}$ & ND & $\begin{array}{l}\text { Request from Gram } \\
\text { panchayat }\end{array}$ & $\begin{array}{l}\text { Proposal from } \\
\text { Uttarakhand FD }\end{array}$ & $\begin{array}{l}\text { Demand from } \\
\text { community }\end{array}$ \\
\hline
\end{tabular}

Abbreviations: OC, other caste; SC, scheduled caste; NGO, non-government organization; JFM, joint forest management; FD, forest department; ND, not determined

\subsection{Selection of the D Village in the Tehri-Garhwal District}

In the Tehri-Garhwal district, multiple villages (and $V P s$ ) were visited in the year 2011 (June to July), out of which five villages were selected for preliminary random sampling by talking to the village head ( sarpanch $^{\text {see Note } 2}$ ) and some villagers including GB and MC, and is indicated in Table 2. To communicate effectively in the local language (Garhwali) an interpreter was used. A village (and $V P$ ) was selected and named "D" village (hereafter, D village) (Figure 2). The primary reason for selecting $V P$ at $\mathrm{D}$ village was because the sarpanch was an organizer of the $V P$ at the village and had been involved in pioneering work to sustain the VPs since the early 1990's, in this district. Further, the sarpanch was also a block committee leader of the 151 VP's in Mussoorie division of the Tehri-Garhwal district. In addition, the D village $V P$ had the village document ${ }^{\text {see Note } 3}$, written in the Hindi language, which was prepared by the Mussoorie Forest Division (hereafter, MFD) [15]. The document was eight pages in total and described some projects during the period 2003 to 2007.

\subsection{Field Research in D Village, Interviews and Data Collection and Analysis}

The field research in D village was conducted between July and August 2012. The lead author had been in local accommodation with a native family during the field work. This fieldwork intended to confirm whether $V P$ governance was active in this region, and questionnaire surveys (semi-structured interviews) for the householders with the help of two local interpreters who could understand the local Garhwali language, were conducted. The interviews were carried out from $28^{\text {th }}$ of July up to $10^{\text {th }}$ August in 2012. There were a total of 51 households in the D village, out of which 41 households responded to the interviews. Each household consisted of a householder, usually a male member, termed the household head, who was interviewed. In case the household head was not present, the other main member of the household was interviewed. In total, 38-household heads and three household members including six women were interviewed. Of the 41 respondents, eight were MC members. The reason for non-interviews with the remaining 10 households was either migration or absence due to work and study outside the village. The data were hand-recorded and later transferred to the computer for analysis using the Excel program (Microsoft Corporation Ltd., USA).

\section{Result and Discussion}




\subsection{People's Perception}

Table 3. The questionnaire for the interviews $(n=41)$

\begin{tabular}{|c|c|c|c|c|c|c|c|}
\hline Type & \multicolumn{2}{|c|}{ Questions } & \multirow{2}{*}{\begin{tabular}{|c|}
$\begin{array}{c}\text { Sample } \\
\text { no. }\end{array}$ \\
$-\frac{33}{8}-$ \\
\end{tabular}} & \multirow[t]{2}{*}{ Average } & \multirow[t]{2}{*}{ High } & \multirow[t]{2}{*}{ Type } & \multirow[t]{2}{*}{ SD } \\
\hline \multirow{23}{*}{ I } & $\mathrm{MC}$ & $-\frac{\text { No }}{-\frac{1}{Y e s}}-$ & & & & & \\
\hline & & $\mathrm{HH}$ number & 41 & 6.76 & 15 & 3 & 2.67 \\
\hline & Family profile & Migration & 40 & 0.70 & 3 & 0 & 0.79 \\
\hline & & Study outside & 40 & 0.43 & 4 & 0 & 0.87 \\
\hline & Caste & 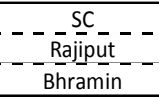 & $\begin{array}{r}22 \\
-10 \\
-\frac{10}{9} \\
\end{array}$ & & & & \\
\hline & & $--\frac{\text { TV }}{\text { Car }}--$ & -41 & $\begin{array}{l}0.63 \\
0.12- \\
\end{array}$ & $-\frac{2}{2}$ & $-\frac{0}{0}$. & $\begin{array}{r}0.54 \\
-0.40 \\
\end{array}$ \\
\hline & Properties)* & Mefrigerator & $\frac{41}{41}$ & $-0.07-$ & $\frac{7}{1}$ & -0 & $\frac{1}{0} \cdot \frac{4}{26}$ \\
\hline & & Dish TV & $40-$ & $0 . \overline{3}-1$ & $-\frac{1}{1}-$ & - & $0.4 \overline{7}$ \\
\hline & & - Clean water & $\begin{array}{r}41 \\
-41 \\
4-1\end{array}$ & & & & \\
\hline & Infrasttucture)* & Firewood & 41 & & & & \\
\hline & & Kerosene & 3 & & & & \\
\hline & & LPG & 24 & & & & \\
\hline & & Agriculture & 35 & & & & $\ldots$ \\
\hline & & Livestock & 2 & & & & \\
\hline & Main livelihood)* & Forest activities & -5 & & & & - \\
\hline & & Employer & 5 & & & & \\
\hline & House & $\begin{array}{c}\text { Wood \& } \\
- \\
\text { mannnual }\end{array}$ & 25 & & & & \\
\hline & construction)* & Wood \& cement & 19 & & & & \\
\hline & & Wood \& straw & 1 & & & & \\
\hline & & $--\frac{\text { Cow }}{\text { Bull }}--$ & $-\frac{38}{41}-$ & $\frac{2.21}{0.27}$ & $-\frac{10}{4}$ & $-\frac{0}{0}$ & $\begin{array}{r}2.02 \\
-0.84\end{array}$ \\
\hline & & Carf & 38 & 0.32 & $-^{2}-$ & {$[-0$} & 0.70 \\
\hline & livestocks)* & Goat & $3 \overline{8}$ & $2.50^{-}$ & 20 & $--\overline{0}$ & 5.00 \\
\hline & & 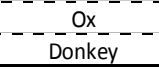 & $\begin{array}{l}36- \\
37 \\
\end{array}$ & $\begin{array}{l}0.64 \\
0.19 \\
\end{array}$ & $-\frac{4}{2}-$ & $-\frac{0}{0}$ & $\begin{array}{r}1.05 \\
-0.52 \\
\end{array}$ \\
\hline & \multicolumn{2}{|c|}{ Distance to VP forest } & 26 & 0.38 & 1 & 0.1 & 0.23 \\
\hline & Collecting & _Yes_ & 32 & . - & - & . & \\
\hline & firewood)** & No & 2 & & & & \\
\hline & \multicolumn{2}{|c|}{ Collecting hours (per week) } & 20 & 7.60 & 9 & 2 & 1.93 \\
\hline & Grazing)** & _. - - Yes & $7 \frac{7}{7}$ & & & & \\
\hline & & Increased & 22 & & & & \\
\hline & Firewood)** & Same & 3 & 2.88 & 3 & 2 & 0.33 \\
\hline & & Declined & 0 & & & & \\
\hline & Fodder)** & - Increased & $-\frac{20}{2}-$ & 2.91 & 3 & 2 & 0.29 \\
\hline & & Declined & 0 & & & & \\
\hline
\end{tabular}

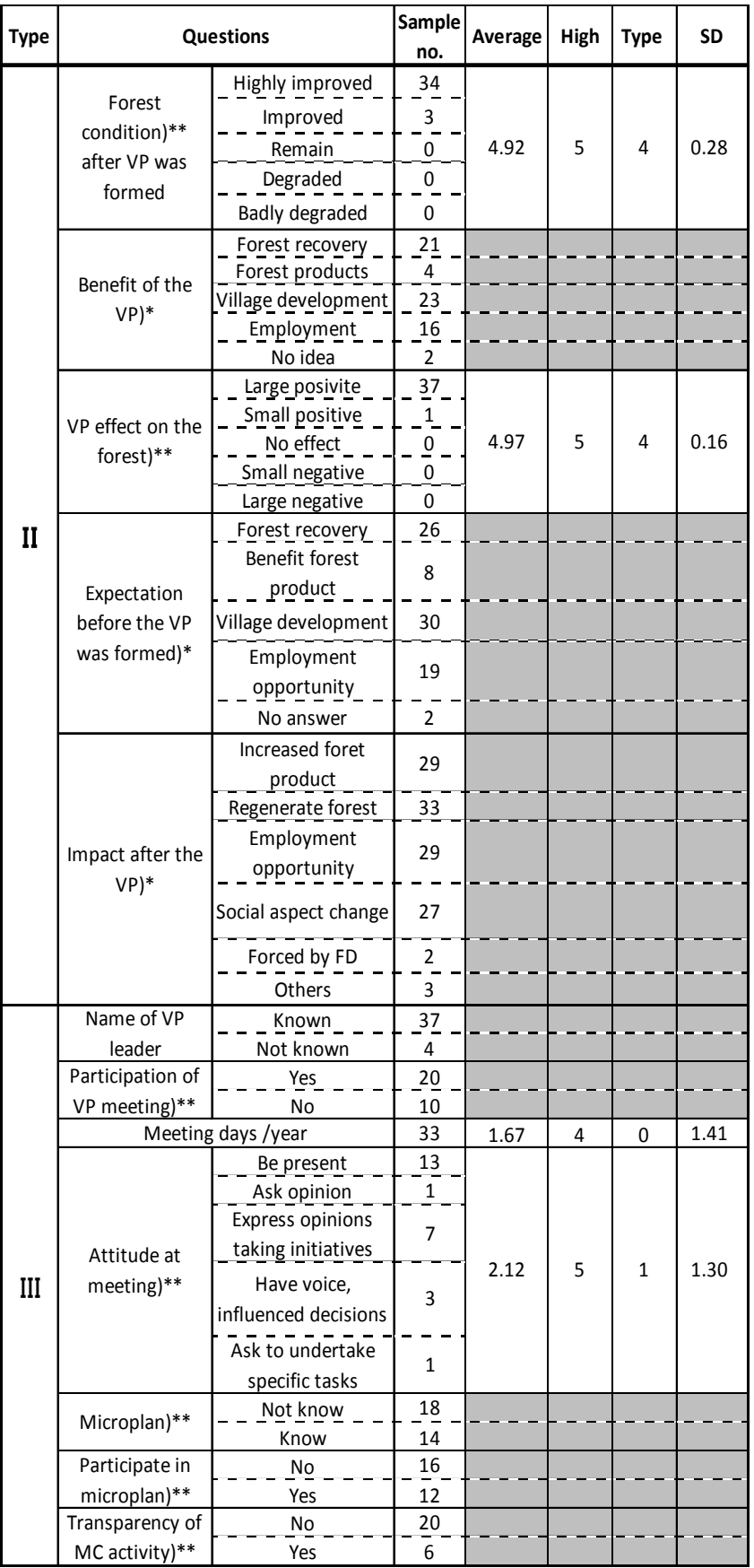

*: Multiple answers allowed.

**: The total answer is less than $41 \mathrm{I}$ : Characteristics of the questions; II: Perception of the $V P$; III: Management of the $V P$.

Abbreviations: MC, management committee; SD, standard deviation; HH, household; SC, scheduled caste; TV, television; PC, personal computer; LPG, liquefied petroleum gas; $V P$, van panchayat; $\mathrm{FD}$, forest department.

The semi-conducted interview (Table 3) revealed that more than $90 \%$ of the interviewee's were satisfied with the condition and management of the $V P$, which was formed in 1993. The satisfaction with the $V P$ was due to the establishment of an orderly system for forest use, decreasing entry of outsiders from the village, and recovery of the forest resources. As for people's impression of the $V P, 81 \%$ of the respondent answered current $V P$ condition has greatly improved since the $V P$ was formed. The reasons mentioned were that the forest was for future generations, increased access to forest products and wage payment from forest-related activities, and social aspects in utilizing the $V P$. A few respondents had some reservations related to the household impacts such as usage and/or damage of some part 
of their land and the felling of fruits trees in order to construct new roads for improved access to the VP. Despite, these minor issues, all the respondent answered that the VP was necessary for all of the villagers for village development and improvement. The villagers had been granted access to the $V P$ area (20 hectares) without constraints, except for the non-felling of trees. It was found that the average distance from $V P$ forest to their residences was $0.38 \mathrm{~km}$. Nine-households had easy access to the $V P$ forest because of its close proximity to their residences. The longest distance need to be travelled to the $V P$ forest by a household was about $1 \mathrm{~km}$. In all, villagers had no major difficulty in accessing the $V P$ forest.

Considering the utilization of the $V P$ forest it was found that the villagers were not allowed to cut standing trees in the $V P$ without permission from the MC. The fact that cutting of trees was prohibited in the $V P$ was well known to every villager. However, they could collect the branches and twigs from trees for firewood, leaves and grasses as fodder for their livestock, as well as non-timber forests products such as the fruits and medicinal plants for themselves. The $V P$ forest was mainly covered with oak (Quercus leucotricophora) and some patches of chir pine (Pinus roxburghii). The other minor species were binmal, kaffle, ayar, and thuner; to note these are local names of the trees in Hindi language. Overall, results indicated that the main utilization of the $V P$ forest was for firewood and fodder. As the oak tree products was mostly used as fuel to cook and heat in their daily life, this tree species could be considered as a necessary item for livelihood maintenance of villagers. Among the respondents $78 \%$ of them depended on firewood, and the remainder used liquefied petroleum gas (hereafter, LPG) as cooking fuel. Moreover, we also found that another fuel source, namely kerosene, was available to the villagers, it was not every household that possessed kerosene oil. The reason might also depend on its (LPG/kerosene) availability and / or the financial status of the villagers. It should be noted that nearly
$90 \%$ of the villagers were listed up below the poverty line $(\mathrm{BPL}){ }^{\text {see Note } 4}$ in $\mathrm{D}$ village. This might indicate the use of firewood mostly for fuel. Moreover, the village (all villagers) had access to electricity which was often not available daily due to electricity/power cuts.

As to why the people's perception was good, a hint was provided by the VP leader (who is also the $\mathrm{D}$ village sarpanch), in his interview, which informed us that before the formation of the $V P$, it was a civil/soyam forest. ${ }^{\text {see Note } 5}$ The land was easily accessible to not only the villagers of D village but also could be used by neighboring villages, for forest-derived benefit. However, there was a problem in that this civil/soyam forest was over utilized in the past resulting in its degradation, and rules for protection could not be maintained well. This lead to the formation of the VP in 1993 along with rules and regulations, which resulted in better access to forest resources for the $\mathrm{D}$ village. Due to an effective and strict enforcement of forest protection and internal regulation of forest use, the $\mathrm{D}$ village $V P$ forest had started to regenerate.

Although, the villagers perceived that $V P$ forest was good for their livelihood, it was not always believed that this could also be good for the environment. This might be related to the educational status of the villagers, who in general were educated at elementary school level (Table 4), mostly under 5 th grade that is equivalent to primary school level. ${ }^{\text {see Note } 6}$ Moreover, as mentioned in Table 4, 63\% of households belonged to scheduled caste (SC). They were rather less interested in forest management, as part of the $\mathrm{MC}$, and more interested in the benefits provided the $V P$ forest. On the other hand, through an interview with a householder who had a position as a teacher at the local school, it was found an interest in the environmental aspects of forest conservation was also important. The teacher, who was educated at the post-graduate level (Master's degree), mentioned, and we quote "more green would make better the environment in our forest".

Table 4. Population of D village (2003)

\begin{tabular}{|c|c|c|c|c|c|c|}
\hline Caste & Family & $\begin{array}{c}\text { Female } \\
\text { (age 18 or over) }\end{array}$ & $\begin{array}{c}\text { Male } \\
\text { (age 18 or over) }\end{array}$ & Boy & Girl & Total Populatiom \\
\hline OC (Other Caste) & 19 & 74 & 69 & 33 & 35 & 211 \\
\hline SC (Scheduled Caste) & 32 & 93 & 112 & 52 & 38 & 295 \\
\hline Total & 51 & 167 & 181 & 85 & 73 & 506 \\
\hline
\end{tabular}

Data obtained from MFD, Mussoorie forest department

Education status of D village (2003)

\begin{tabular}{|c|c|c|c|c|c|c|}
\hline Total & $\begin{array}{c}\text { M.A } \\
\text { (Post-graduate) }\end{array}$ & $\begin{array}{c}\text { B.A. } \\
\text { (Graduate) }\end{array}$ & Inter (12th) & $\begin{array}{l}\text { High School } \\
\text { (10th) }\end{array}$ & $\begin{array}{c}\text { Junior School } \\
\text { (8th) }\end{array}$ & $\begin{array}{c}\text { Primary School } \\
\text { (5th) }\end{array}$ \\
\hline 105 & 2 & 4 & 9 & 14 & 31 & 45 \\
\hline
\end{tabular}

Data obtained from MFD, Mussoorie forest department. Abbreviations: M.A., Master of Art; B.A., Bachelor of Art 


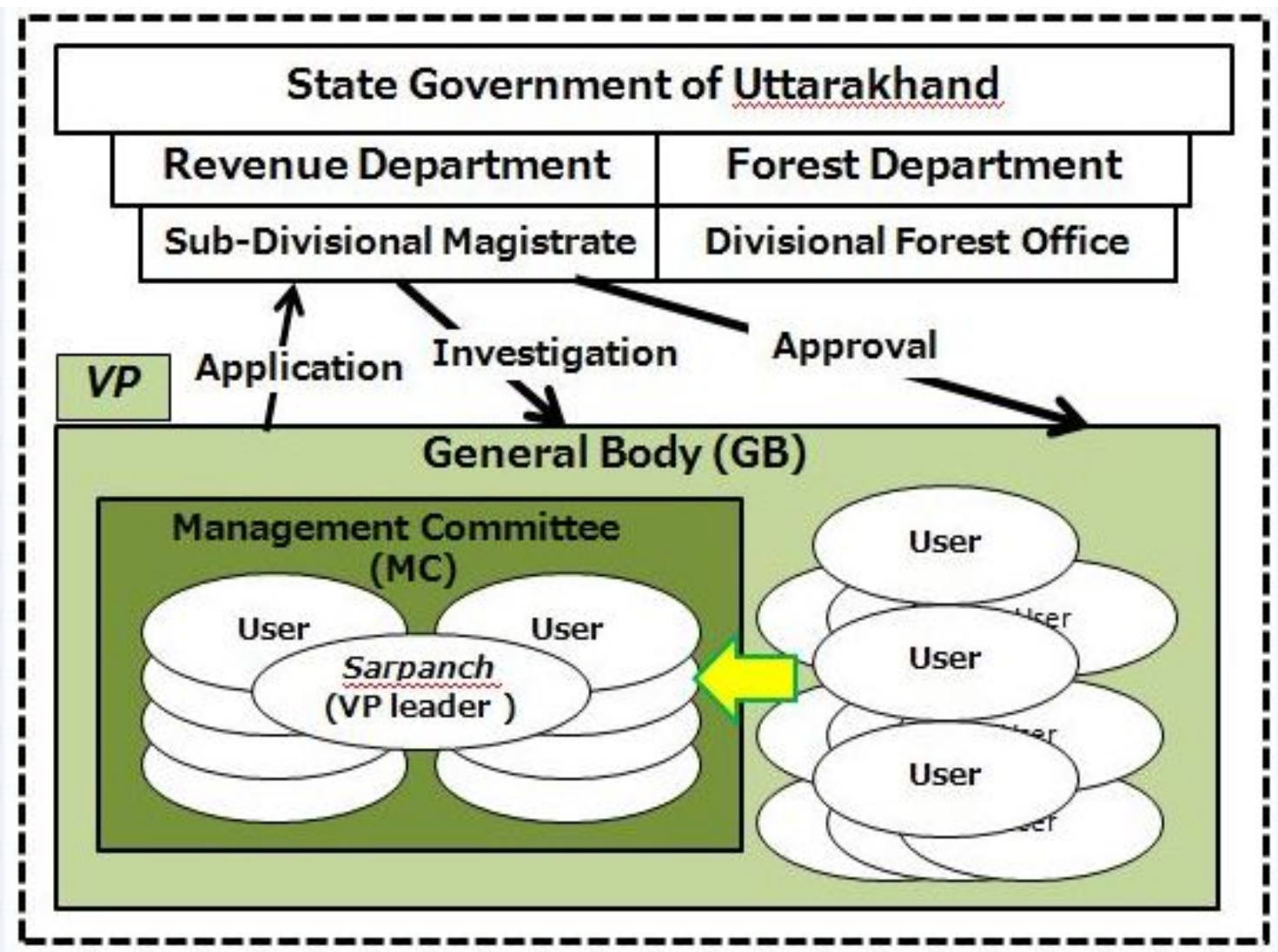

Figure 3. Formation of $V P[16]$

\subsection{Characteristics of Management Committee}

The VP MC in $\mathrm{D}$ village consisted of nine members, at the time of the study period (2012). According to the VP Rules of 2005 [16] which were issued by the state of Uttarakhand, the FD specified responsibilities of the MC (Figure 3). The $\mathrm{MC}$ consisted of nine members: eight were selected from the GB though a democratic process, and the ninth member was the sarpanch. Moreover, the secretary from the FD should be included in the MC; however, this was not the case in D village. It is to be noted that since the 2003-2007 and to the 2008-2012 periods, the MC members remained the same, including the leader of the $V P$, the sarpanch. The sarpanch was entrusted with a duty to convene all MC meetings, to control and transact business, to preserve order, to supervise the staffs and establishment, and to carry the resolutions of the MC. Additionally, it was within the MC's jurisdiction to take firewood and fodder under their own rules and protect trees from damage; protect $V P$ forest from encroachment; fix boundary pillars, construct boundary walls; protect forest from illicit felling, lopping, fire and other damage; and protect, conserve, and improve the forest in general. As per the interview with the villagers, it was revealed that the sarpanch in the $\mathrm{D}$ village has not changed since the $V P$ was constituted in 1993 . The reason is not only his selection by the villagers to this post, but also might lie is his expert knowledge of the village, and he was the person who established the $V P$ in $\mathrm{D}$ village at that time. As can be seen from the hand-drawn map in Figure 4, the sarpanch had a detailed knowledge of the $V P$ forest and the village. 


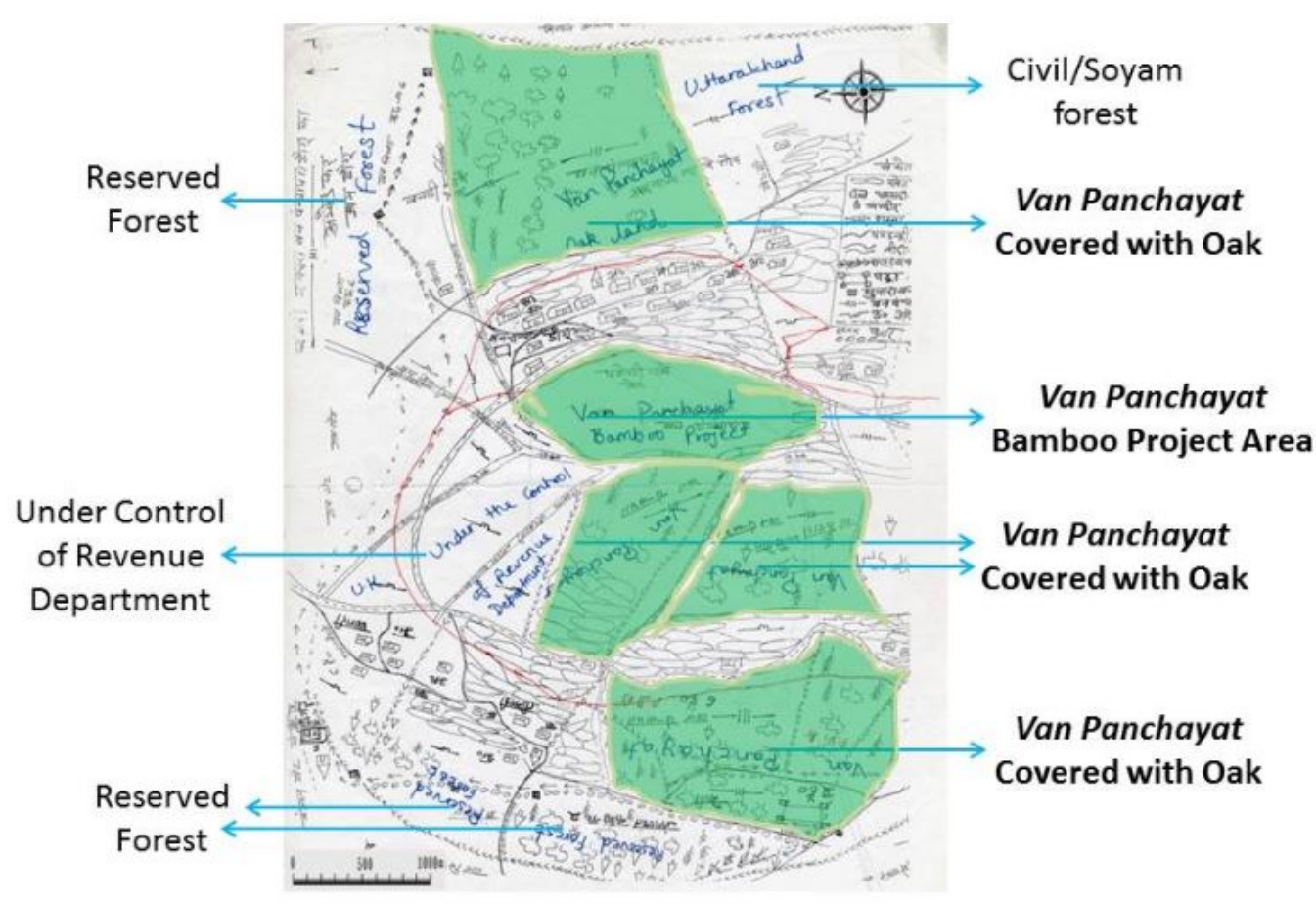

Figure 4. A sketch of the D village (redrawn from the original by the sarpanch in 2012)

Table 5. Relation between MC member's composition and factors

\begin{tabular}{l|c|c|c|}
\hline \multirow{2}{*}{ Factors } & \multicolumn{3}{c}{ Explained Variable : MC members or not } \\
\cline { 2 - 4 } & $\boldsymbol{\chi}^{\mathbf{2}}$ test & Fishers $\boldsymbol{p}$ & Result \\
\hline Caste & 4.04 & - & Rejected \\
\hline Migrant & 0.303 & 0.27 & Accepted \\
\hline Outside study & 0.74 & 0.23 & Accepted \\
\hline Cell phone & - & 0.5 & Accepted \\
\hline Dish TV & - & 0.17 & Accepted \\
\hline LPG & - & 0.0003 & Rejected \\
\hline VP distance & - & 1.32 & Accepted \\
\hline Collecting firewood & - & 0.37 & Accepted \\
\hline Grazing animals & - & 0.29 & Accepted \\
\hline
\end{tabular}

Critical value: $\chi^{2}>4.06(5 \%), p<0.05$

From the investigation into the MC, two characteristics could be ascertained, first, selection of the MC members and second, utilization of the LPG among the villagers. Interviews regarding the selection of the MC members revealed that the consistency of caste was not fair in their selection. This was reasoned looking at the caste proportion of the villagers, where more than $60 \%$ were SC (Table 4). A higher caste status could be a factor for selecting the $\mathrm{MC}$ members. As for the co-relation between $\mathrm{MC}$ member selection and caste representation in $\mathrm{D}$ village, the significance probability of 0.044 , and $\chi$ (chi-squared) was 4.04. These were over the critical value of 3.84 (using a level of significance of 0.05). This result indicated that consistency of caste was not fair in selecting MC members when considering the proportion of the villagers.

Another important factor involving the MC was the use of LPG. To promote forest conservation, the government has issued non-binding orders that both the MC members and non-members (GB) use the LPG provided under various schemes. Table 5 revealed how people were independent of firewood utilization between MC and the non-MC members. The interview showed that the MC members have less LPG possession than the non-members. From the Fisher's significance probability, the value for the relationship between MC and LPG was 0.0003 , which is under the level of 0.05 . Thus we could see a bias for LPG use and MC composition. In other words, those who did not use LPG were prone to use firewood. It was also suggested that those 
who did not possess LPG were inclined to work and study outside of the village. Except for caste and LPG, no other specific household factors (such as proportion of migration, study outside of D village, possession of cell phone and satellite TV antennas, distance to $V P$, collection of firewood, and possession and grazing of livestock) affected the results of the statistical analysis as shown in Table 5.

We further asked the villagers about their participation in the MC meetings. All members of the GB could take part in the meeting that the $\mathrm{MC}$ organizes four times a year. Interviews revealed that $24 \%$ of the respondents had not participated in the meeting. Non-attending villagers were found to be involved in other more important works or in some cases the householders were absent from the village due to work outside the village or migration. Further, some villagers were not aware about such meetings. The Table 6 revealed the villagers participation and involvement in the meeting. The $\mathrm{MC}$ members outlined their attitude during the meeting: they expressed opinions, whether or not solicited; took part in presenting/discussing various initiatives; had a voice and influence in the group's decisions; asking the members/villagers (or volunteers) to undertake specific tasks, which were usually asked by the chairman. It was observed that most of the participants were just present without saying anything at the meeting. When asked, as to the non-participation in the meeting, one respondent explained, and we quote "we cannot get money to take part in forestry". Although the FD subsidizes tree plantation, which was the most expensive support for the forest-related activities from the government, the money did not go to the people who participated in the planting. One lakh rupee per year from FD was enough to prepare nursery trees but not to deliver income to the people in relation to work done during the plantation of trees. As the forest-related works were assumed to be voluntary that might result in a lack of participation among the GB in the meetings.

Table 6. The question, when you attended the $V P$ meeting, how was your attitude?

\begin{tabular}{|l|c|}
\hline \multicolumn{1}{|c|}{ Choice of Answer } & Number of People \\
\hline 1. Just present at the meeting without saying anything & 11 \\
\hline 2. Being asked an opinion in specific matters without guarantees of influencing decisions & 3 \\
\hline 3. Expressing opinions, whether or not solicited, or taking initiatives of other sorts & 5 \\
\hline 4. Having voice and influence in the group's decisions & 3 \\
\hline 5. Being asked to (or volunteering) to undertake specific tasks & 1 \\
\hline 6. Not answered & 6 \\
\hline Total & 29 \\
\hline
\end{tabular}

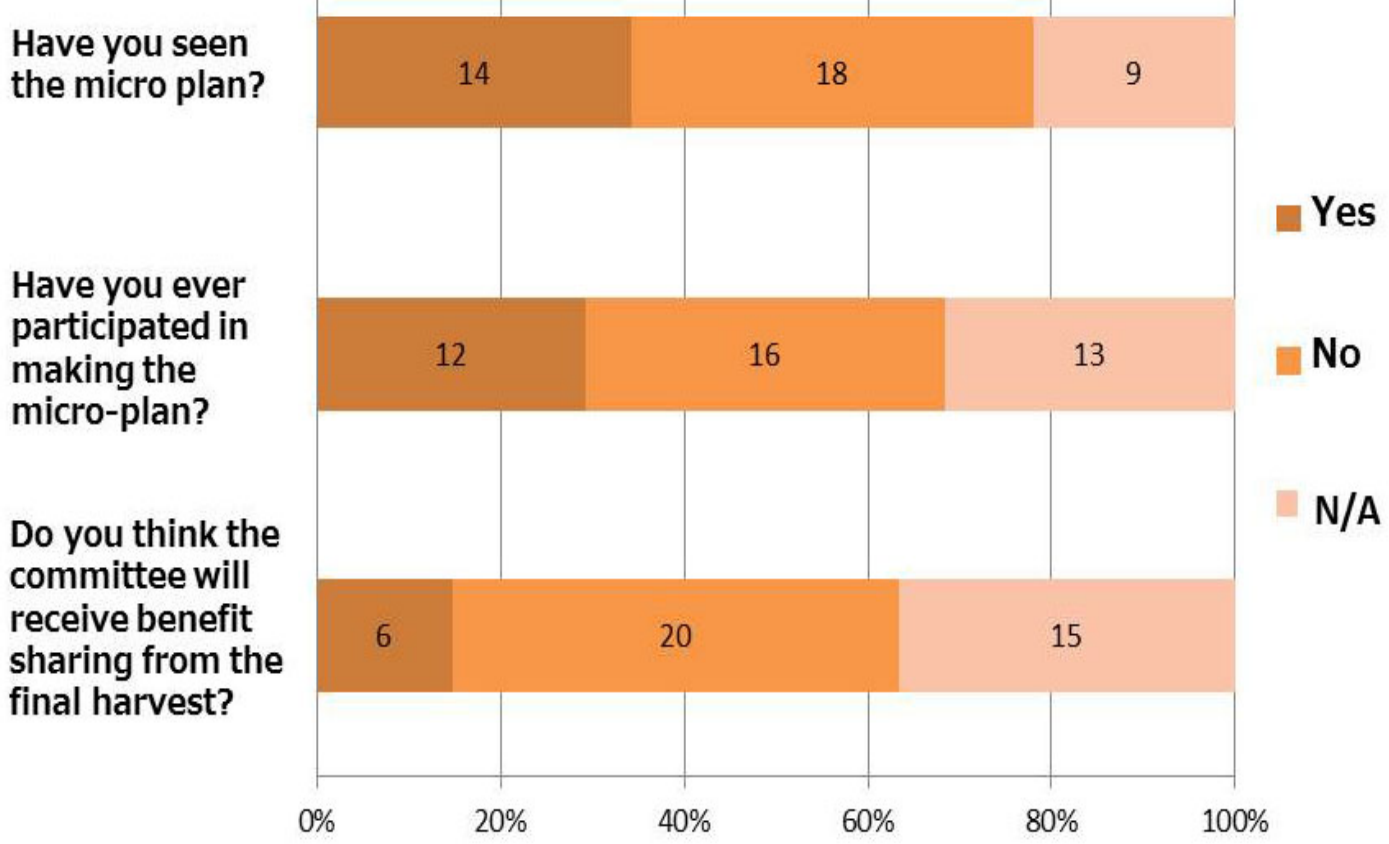

Figure 5. People's recognition of the $V P$ 
Finally, we would like to briefly mention about the micro-plan, as part of the MC duties. As for the VP Rules, $\mathrm{MC}$ shall make their own decisions and rules on how to govern the $V P$ forest for the next five years. Micro-plan was important for decision-making with the annual implementation plan. The interview with the sarpanch revealed that the current micro-plan was the latest one and that had not been revised since 2002. Figure 5 clarifies people's participation in their micro-plan prepared by the MC. Results revealed that $34 \%$ of respondents answered in the positive regarding knowledge of the micro-plan, the remaining $64 \%$ had no knowledge of it. Twenty-nine percent of the respondents participated in the meeting to make the micro-plan. The proportion of the $\mathrm{MC}$ members in $\mathrm{D}$ village was $18 \%$, which means $9 \%$ of the GB could take part in the meeting to make the micro-plan. Forty-nine percent of respondents believed that they received few benefits from MC work. However, $15 \%$ of respondents answered that the MC received benefits from VP. This suggested that the micro-plan was not released to all the villagers. Taken together, our results show a general lack of people's participation in the $V P$ meetings and in the micro-plan discussion. This might be related to the functioning of the MC rather than the will of the people to not actively participate.

\section{Conclusions and Future Prospects}

This research presented the case study of a $V P$ (D village) that was highly recommended by the FD officers. The presence of an active sarpanch in the D village, who had full knowledge of the land and showed strong leadership, made the $\mathrm{D}$ village $V P$ successful, which was revealed by analyzing the people's perception. The good perception might be due to the presence of a large oak forest in the $\mathrm{D}$ village $V P$, which had a better impact for forest utilization. Prabhakar and Somanathan (1998) reported that dense oak forests were $15.6 \%$ more common in the $V P$ than in other types of forests [17]. The $V P$ of D village was categorized to that common $V P$ covered by dense oak forest. The higher proportion of oak indicates that the $V P$ plays an important role in conservation of forest in the Himalayas [18]. In other words, the $V P$ forest dominated by oak trees provided better conditions for environmental conservation and the maintenance of people's livelihood.

Looking at the MC characteristics, we found that there were some issues regarding the management practices in the $V P$. It can be said that there is a need for more transparent $\mathrm{MC}$, which might lead to better forest management and livelihood improvement. Even though the result of this case study is not a representative of the entire picture of $V P$ management in the state of Uttarakhand, it is important to clarify the reality of $V P \mathrm{~s}$ at the level of local people and aim at decreasing serious poverty among forest-dependent people. Moreover, as the regional differences exist in forestry management, old $V P$ s practices in Kumaon and new
$V P \mathrm{~s}$ in Garhwal are most different, thus requiring a district wise comparative study in the future.

The case of $\mathrm{D}$ village presents several issues and challenges in association with the forest management of $V P$ as follows. First, the micro-plan should be prepared every five years according to $V P$ rules and $\mathrm{MC}$ members should be elected every five years. In this context, the selection of MC members should consider fairly caste, gender and poverty. However, it is very difficult for lower castes to resist the wishes of higher castes even if they formally have the right to do so. Villagers also need to promote democratic elections for the MC and chairperson. Yet, the chairperson and the MC members have status and the strong existence of caste does not change this situation. Government affirmative action should expand to not only include gender bias but also caste. Second, to maximize the benefits for the MC, it would be desirable to promote the MC's participation, maximize the right of decision-making, and improve management ability. Furthermore, it is important to commit to the VPS and enhance the facilitation of MC for FD, which is necessary for obtaining administrative support particularly from the RD. Third, all the people have to be committed to the MC. This is important for the purpose of better forest management and utilization. Higher education may be a factor and the key to not only for participation in forest management but also developing village activity, that is, if the people who are educated remain and dwell in the village. Fourth, instead of firewood, local people need to consider a change to use more LPG under government support for obtaining and using modern access. Every household uses firewood as the main cooking fuel; most of it is gathered. A lack of clean fuel is a major problem facing most rural woman in India. Women's mortality risk from smoke-related infection is $50 \%$ higher than men's [19]. Even though the villagers possess LPG, they are not utilizing firewood, and it is also necessary for forest conservation. Fifth, it is important to understand and inform the readers that the model of participatory forest management depends on the situation of the ground reality and the regional status, as demonstrated in this study.

\section{Acknowledgements}

The field survey in India would not have been possible without considerable cooperation from people in D village of Tehri-Garhwal in UK state, and all the respondents who kindly answered to the questions. Special appreciation is given to Mr. H. S. Rawat who offered comfortable accommodation during the field surveys, as well as Dr. Vinod Bhatt and Mr. Hari Raj who both supported the NGO "Navdanya" and made great effort to support the field activities. The UK Forest Department staffs, who supported the collection the data, and Dr. Prakash Dhaila (G. B. Pant Institute of Himalayan Environment and Development) who supported the research in Almora and gave academic advices regarding $V P$ are highly appreciated. Last but not the least, appreciation is due to the Indian NGOs, Earthwatch Institute 
India Delhi, CHEA in Nainital and RELK in Dehradun for their kind support to develop the field survey and $V P$ visits. I also would like to express my deepest gratitude to Dr. Yasutaka Hama for academic instruction and constructive counsel to make this research clear.

\section{Notes}

1. According to Gairola (2009) [20], VPs have survived since 1931, and longest standing example, because the evidences such as Jammu and Kashmir, Rules for Villages Forest Management in 1934, Kangra Cooperative Forest Societies in Himachal Pradesh in 1941 to 1973, and Rudimentary form of Joint forest Management, Arunachal Pradesh in 1948, show that similar efforts at other places did not give compatible results.

2. Sarpanch who is the term used for the chairperson of the management committee is the leader of $V P$.

3. It was undertaken for the micro-plan of this village by Sarpanch. In general, the villagers in Van Panchayat have their own specific rules called a micro-plan, whereby they prepare the regulations and determine the methods of utilization. They may create monitoring, sanctioning and arbitration devices to resolve the vast majority of disputes within local spaces (Agrawal and Yamada 1997) [21].

4. D village members were listed up as under below poverty line at the website (Tehri Garhwal (Uttarakhand) District Administration (2008) Fresh Below Poverty Line List(BPL-2002). Retrieved December 19, 2012, from http:/www.ua.nic.in/tehri.nic.in/(pages/view/58/60-fresh-be low-poverty-line-list (bpl---2008).

5. Civil/Soyam Forest is managed by the Gram sabha (village council), and usually people have unlimited rights and concessions for use, whereas the forest department controls the reserve forests where people have limited rights and concessions.

$6.5^{\text {th }}$ : primary school: $6-11$ years old

\section{REFERENCES}

[1] Salafsky, N. and Wollenberg, E., 2000, 'Linking Livelihoods and Conservation: A Conceptual Framework and Scale for Assessing the Integration of Human Needs and Biodiversity', World Development, vol. 28, no. 8, pp.1421-1438.

[2] Abbot, O., Thomas, L., Gardner, A., Neba, E., Khen, W., 2001, 'Understanding the links between conservation and development in the Bamenda Highlands Cameroon' World Development, no.29, pp. 1115-1136.

[3] Arnold, M., 2001, Forestry, Poverty and Aid, CIFOR Occasional Paper, no. 33, Bogor, Indonesia: Center for International Forestry Research.

[4] Ota, M., Antilb, S., Bhattacharya, P., and Masuda. M., 2014, 'Presence and effectiveness of material benefit provisions under joint forest management in India: The cases of world bank-aided village forest committees in Madhya Pradesh', Forests, Trees and Livelihoods, no.3, vol. 23, pp. 159-174.

[5] Saito-Jensen, M. 2008. Do local villagers gain from joint forest management? Why and why not?: Lessons from two case study areas from Andhra Pradesh, India. Tokyo, Japan: International Cooperation Agency.

[6] Agrawal, A., and Ribot, J.C., 1999, 'Accountability in decentralization: a framework with South Asian and African Case', The Journal of Development Area, vol. 33, no. 4, pp.473-502.

[7] Ballabh, V., Balooni, K., and Dave, S. 2002. Why local resources management institutions decline: A comparative analysis of Van (Forest) Panchayats and Forest Protection Committees in India. World Development, 30: 2153-2167.

[8] Gairola, H. and Negi, A.S. 2011. VPs in Uttarakhand: A perspective from practitioners. In Community based Biodiversity conservation in the Himalayas, eds. Gokhale Y; Negi AK, New Delhi: The Energy and Resource Institute.

[9] Guha, R. 1983. Forestry in British and post British India: a historical analysis. Economic and Political Weekly 18:1949-1947.

[10] Singh, K. and Ballabh, V. 1991. People's participation in forest management: Experience of Van Panchayat in UP hills. Wastelands News 7: 5-14

[11] Balooni, K., Ballabh, K., and Inoue, M. 2007. Declining instituted collective management practices and forest quality in the Central Himalayas. Economic and Political Weekly, 42: 1443-1452.

[12] Agrawal, A. 2005. Environmentality: technologies of government and the making of subjects. Durham: Duke University Press.

[13] Sarin, M. 2001. Disempowerment in the name of 'participatory' forestry?: Village forests joint management in Uttarakhand. Forests, Trees and People, Newsletter 44.

[14] UFD. 2007. Van panchayat Atlas 2007. Dehradun: Forest Department, Uttarakhand.

[15] MFD. n.d. Forest Development Agency 2003-2007. Tehri Garhwal, Uttaranchal: Mussoorie Forest Division.

[16] UFD. 2005. The Uttaranchal Panyayati Forest Rules. 2005. Dehradun: Forest Department, Uttaranchal.

[17] Prabhakar, R., and Somanathan, E. 1998. Property Regimes and Deforestation: A quantitative study of the Central Himalaya.

[18] Rawat, V.S., Tewari, A., and Rawat, Y.S. 2011. Local level Community Forest Management an Effective Tool in Conserving Forest Biodiversity. Russian Journal of Ecology 5: $388-394$

[19] Agrawal, B. 2001. Participatory exclusions, community forestry, and gender: Analysis for South Asia and a conceptual framework. World Development 29: 1623-1648.

[20] Gairola, H. 2009. Experience in VAN PANCHAYATs. Workshop on Potential biodiversity rich community conservation areas in Uttarakhand. The Energy and Resource Institute and Department of Forestry HNB Garhwal University. Dehradun, India. 
[21] Agrawal, A. and Yadama, G.N. 1997. How do local institutions mediate and population pressures mediate market and population pressures on resources?: Forest panchayats in Kumaon, India. Development and Change 28: 435-465.

[22] Rawat AS. 1999. Forest management in Kumaon Himalaya, struggle of the marginalized people. Indus Publishing Company, New Delhi.

[23] UFD. 2011. Uttarakhand Forest Statistics 2010-2011. Dehradun: Forest Department, Uttarakhand. 